\title{
A Period Analysis on Values Shaped by Culture: Turkish and Armenian Women's Clothing
}

\author{
Berna Yildırım Artac \\ Turkey \\ Emine Koca \\ Faculty of Art and Design, Gazi Universty, Turkey
}

Doi:10.19044/esj.2018.v14n32p131 URL:http://dx.doi.org/10.19044/esj.2018.v14n32p131

\begin{abstract}
Written works such as miniatures, engravings and travel books, which contain visuals related to the Ottoman State, are considered to be documents bearing witness to history and imparting information about the daily life of the Ottoman Empire. These documents contain visuals of the people living in the Ottoman State, imparting, among other information, clues on the characteristics of the clothes of the period.

In the Ottoman state cultural interaction often overrode attempts to create boundaries in the forms of clothing belonging to distinct communities. The resulting similarities in clothing form the starting point of this study. Focusing on the examination of clothes belonging to Turkish and Armenian women who lived in the Ottoman Empire in the18th and 19th centuries, this study aims to determine the similarities and differences between the clothing cultures of the two communities. A total of 22 images reflecting the everyday clothing of Turkish and Armenian women were examined with the help of a clothing examination form repared by the researchers. The visuals were analyzed according to form and usage, design features were explained, and the similarities and differences between the women's garments were interpreted.
\end{abstract}

Keywords: Turkish, Armenian, clothing, garments, culture

\section{Introduction}

When studying civilizations, societies and cultures, it is necessary to examine visual documents as well as written documents of historical events. The visuals of abstract and concrete cultural products, reflecting the settlement patterns, lifestyles, beliefs and values of the societies that produced them, are among these non-written documents. Clothes are the result of long-standing experience and have an important place among these cultural products. Since clothes maintain continuity in culture, they also play an important role in 
reflecting the social, economic, political and cultural characteristics of societies and periods.

In traditional societies, an individual's clothing reflects the characteristics of that individual's social class. Clothes define certain roles and features. People wear clothes appropriate to their age, their gender, their position in society and their profession (Barbarosoğlu, 2013: 28). Clothes have not only been determinants of concepts such as class, religion and nation in the historical process, the colors and forms of clothing have also been determinative in protecting the social hierarchy (Koca and Koç, 2014: 373). For this reason, the forms of clothing and the garments forming them have the characteristic of cultural documents. Societies have shaped their traditional clothing by assigning meaning to the garments according to the rules of community, or of the state they live in. As in all civilizations, the formal characteristics of clothes, varying for each community with a different culture in the Ottoman Empire, were formed according to cultural facts.

In addition, migration was another important factor that has affected the clothing culture of both countries. With migration, communities moved not only from one place to the other, but also initiated an interactive process where both the immigrants and the host country found themselves subject to change. With this interaction process, the cultures of both the immigrant and the local communities were reshaped and a new, richer culture began to emerge (Koç\&Saatçığlu, 2016:199). This situation had a particular effect on clothing features of Ottoman communities and thus resulted in the similarities between different cultural values.

Clothing is not only a symbolic language, but also expresses what it intends to in the best possible way anywhere and anytime. In the multi-cultural Ottoman society, clothing carried symbolic meaning and carried implications in forms and colors, hence clothes have the characteristic of cultural documents used as tools to express the social structure of the state (Meriç, 2005: 405).

In the Ottoman Empire, the clothes of different ethnic and religious communities reflected their own characteristics and were key in making them distinguishable in public. The form of clothing was also often prescribed by law. Through clothing, the differences between the social groups in the Ottoman Empire and the wearers' positions in society were revealed.

Due to both the rich cultural heritage and the competitive power of textile production in the Ottoman Empire period, textile and apparel products almost became more of a form of visual communication language rather than clothing. Clothing was an issue that was extensively discussed especially in terms of communication language and was also meticulously controlled at the state level (Koç, 2009: 97). Since the clothing patterns, considered so important in a state structure as large as the Ottoman State, also had symbolic roles, research and documentation studies in this field are clearly culturally necessary. 
Since clothing was part of social mores as well as one of the key elements in the preservation of social hierarchy, great importance was placed on its preparation, the richness of design, the and type of fabric and embellishments. This is emphasized by many decrees by sultans outlining the colors, shapes and fabric quality of clothing prescribed (Koca, 2009: 64). Clothing was used as an important symbol in the preservation of the hierarchical order, details such as the shape, cut, color or fabric quality of the clothing or the headdress often being determinants of class and rank in the multi-ethnic structure of the state. In her travel book Family Life in Turkey (Türkiye'de Aile Hayat,, 2009), Garnett states that the people living together in the Ottoman Empire continued their social lives with the images from their past, and that they demarcated themselves from each other with different looks as well as different characters. It is possible to outline more examples of this fact period with written and visual information in travel books from the period about women's clothing in the Ottoman Empire.

Beginning with Ottoman portraiture, the foundations of which were established around the 15 th century, in the 17 th century albums were becoming more and more popular. Prepared both for the place and tourists visiting Istanbul, these clothing albums( catalog mu demek lazim bilemedim?), increased in number, and miniatures portraying prophets, heroes, sultans, and love stories were being painted on big sheets of paper. These miniatures, also functioning as significant historical documents, have thus trasmitted the culture and clothing features of that age to today.

It is common knowledge that the clothing of women who lived within the borders of the Ottoman Empire, regardless of the region or ethnic group, consisted of various layers of clothing, this being the most characteristic feature of Turkish dressing culture. In general, the parts of the set in Ottoman clothing culture are comprised of three layers:

1. Underwear, i.e. shalwar and shirts,

2. Outerwear; i.e. the entari (gown), kaftan and cepken (vest)

3. Street garments, i.e. the ferace and outer kaftans (Koç, 2009: 86)

This study aims to examine the characteristics of the everyday clothing of the Turkish and Armenian women living in Ottoman society in the 18th and 19th centuries, and to interpret their similarities and differences in terms of cultural interaction. In the research, the shape, fabric, color, embellishments, usage and accessories $n$ the everyday clothing worn by female figures in the engravings and paintings of the period were examined, and the interpretation of similarities and differences in clothes in terms of cultural interaction was attempted.

In order to achieve the overall objective of the research, answers to the following sub-objectives were sought: 
1. What are the styles and characteristics of the everyday clothing of Turkish women?

2. What are the styles and characteristics of the everyday clothing of Armenian women?

3. What are the similar and different characteristics of the everyday clothing of Turkish and Armenian peoples in Ottoman society?

\section{Method}

In this qualitative research study, carried out in order to examine the characteristics of the everyday clothing of Turkish and Armenian women living in Ottoman society in the 18th and 19th centuries, and to interpret the similarities and differences in terms of cultural interaction, documentary survey and examination methods were used together.

The documentary survey system is the collection of data by examining existing documents. The examined documents are all kinds of images, letters, reports, books, encyclopedias, official and private writings and statistics, memoires and life stories, marked immediately by past phenomena or written or designed later, reminiscing about past phenomena (Karasar, 2007: 183). The engravings and paintings (showing the characteristics of the clothing of the Turkish and Armenian peoples constituting the Ottoman society between the 18th and 19th centuries) that were included in the research were classified and examined with the document examination method "comprising the analysis of written material containing information about the phenomena to be studied" (Yıldırım \& Şimşek, 2008, 187).

The research universe of this study consists of the clothing of all peoples living in the Ottoman society in the 18th and 19th centuries, while the research sample consists of available written sources, engravings and paintings about the clothing of Turkish and Armenian of the period. The research material has been restricted to paintings and engravings of the period for the purposes of availability and consistency.

A total of 22 engravings and paintings included in the scope of the research, reflecting the daily clothing of Turkish and Armenian women, were examined with the form of a clothing examination form (observation form) prepared by the researchers. The visuals of clothes, presented in tabular form, were examined with regard to their shape and usage. Design features such as color, fabric and ornaments were explained, and differences and similarities between the women's garments belonging to the two communities were interpreted. Since it was impossible to date some of the visuals of clothes accurately, these visuals were interpreted according to the rule of thumb that in traditional lifestyles, clothing remains unchanged for many years. 


\section{Findings}

\subsection{Everyday clothing of Turkish women}

Clothing belongs to the most important elements of a nation's culture. Communities set themselves apart from others through their own unique culture of clothing. It is possible to say that clothing is the mirror of a person on the individual level, and of an era or a society, in general. The Turkish society has had a rich clothing culture for centuries. This wealth is visible in the shapes as well as the materials of clothes. The extensive historical background of Anatolia, the influence of Central Asia and contacts with other cultures played important roles in the diversity and richness of Turkish clothing (Tezcan, 1983: 259).

Nearly all travel books about the East include some portrayals of Oriental women, and perhaps the most fascinating among these is the Turkish woman who lives a life closed to the outside for religious reasons. Travelers have often described clothing and lifestyle of Turkish women, the harem, etc., although they usually did not even have a chance to see these women's faces. Many travel books are full of praise and important statements about the physical characteristics of Turkish women (Gürer, 2010: 207).

Thanks to the writings of travelers to Ottoman lands, information about the local styles of clothing from the period is available, and interpretations are possible. One of the most important travelers to the Ottoman Empire is Fynes Moryson. His Itinerary, written in the 1590s, includes the following information about Ottoman women's clothing:

The Turkish women weare smocks (of which fashion also the mens shirts are) of fine linnen, wrought with silke at the wrests, vpon the sleeues, and at the skirts; and a long cote of silke, wrought with needle-worke, and edged, with sleeues close to the arme, and at the breast, with their necks naked. The womens gownes are much like those of the men, for cloth and fashion, and in like sort without lace, and plaine without cutting, and open before, so as the smocke is seene; and they weare linnen breeches as men, by day and night, or else such breeches of cloth, as men weare, and both these open at the knee; and as the men, so likewise the women, haue no collar of any garment, but their neckes bee naked, and the women haue Pearles hanging in their eares. But they seldome weare shooes or stockings like men, but commonly Buskins of light colours, adorned with gold and siluer, or with Iewells if they be of the richer sort, or wiues of great men; and these they weare onely abroad, for at home their feet be naked, \& as men, so they sit crosselegd vpō carpets. They weaue vp their haire in curious knots, \& so let them hang at length, \& deck the haire with Pearle and buttons of gold, 
and with Iewels \& flowers of silk wrought with the needle (Gürtuna, 2002: 1777; Moryson, 1617: p 176).

Koç, Koca and Vural, (2015: 93) state that the traditional clothing comprised of şalvar, shift and kaftan continued until the $17^{\text {th }}$ century, and that this basic shape of clothes persisted in the $18^{\text {th }}$ century despite changes in fabric, patterns, color and quality. One of the most important characteristics of Turkish dressing culture is that while fabrics and other materials changed according to the period and the social environment, women's and men's clothing consisted of the same main items, differences being created with details such as hats and headdresses, ornamentation, and usage.

The botanist of the royal French gardens, Joseph Pitton de Tournefort, and visited Greece, the Turkish Empire, Armenia, and Georgia. Commenting that Turkish women had an imposing style of dress, he described their clothes in detail:

Though the Women in Turkey do not shew themselves in publick, they are yet very magnificent in their Habits. They wear Breeches like Men, which reach as low as the Heel in the manner of a Pantaloon, at the end of which is a very neat Sock of Spanish Leather. These Breeches are of Cloth, Velvet, Sattin, Fustian, Brocade, or fine Linen, according to the Season, and the Quality of the Wearer. [...] The Turkish Women wear upon their Shift a Waist-coat, and upon that a kind of Cassock of very rich Stuff: this Cassock is button'd down below the Breast, and gilt about with a Girdle of Silk or Leather, with some Plates of Silver enrich'd with Jewels. The Vest they wear upon the Cassock, is of a Stuff which is more or less thick, according to the Season; and the Fur of it is more or less costly, according to the Person's Condition. They often fold one part of the Vest over the other, and the Sleeves reach to the Fingers-Ends; and they commonly carry their Hands thrust in at the Slits in the side of the Vest. Their Shoes are exactly like the Mens, that is, embellish'd with a Border of Iron about the Heel. To give their Stature the best Advantage, instead of a Turbant, they wear a Bonnet of Pasteboard, cover'd with Cloth of Gold, or some handsom Stuff. [...] as the Women among the Turks are obliged to cover themselves all over, they have a Veil upon the Bonnet, which hangs down to the Eye-brows; the rest of the Face is cover'd with a fine handkerchief, ty'd so strait behind, that the women look just as if they were bridled (Gürer, 2010: 189; Ozell, 2014:70).

Koç (2009: 97-98) points out that the rich appearance of Turkish clothing culture is due not only to the characteristics of the materials and cuts, but more importantly, to the fact that layers are used very prominently. Koç and Koca state that (2012:143) in Turkish culture garments are used more or less in a 
similar way in speacial occasions or daily life. According to them, the difference lies in the material used and the ornaments added to the garments.

Refik (1998: 78) notes that the indoor clothing culture Turkish women is more vivid and flamboyant, since they are free to dress as they want within the home.

Table 1: Everyday Clothing of Turkish Women

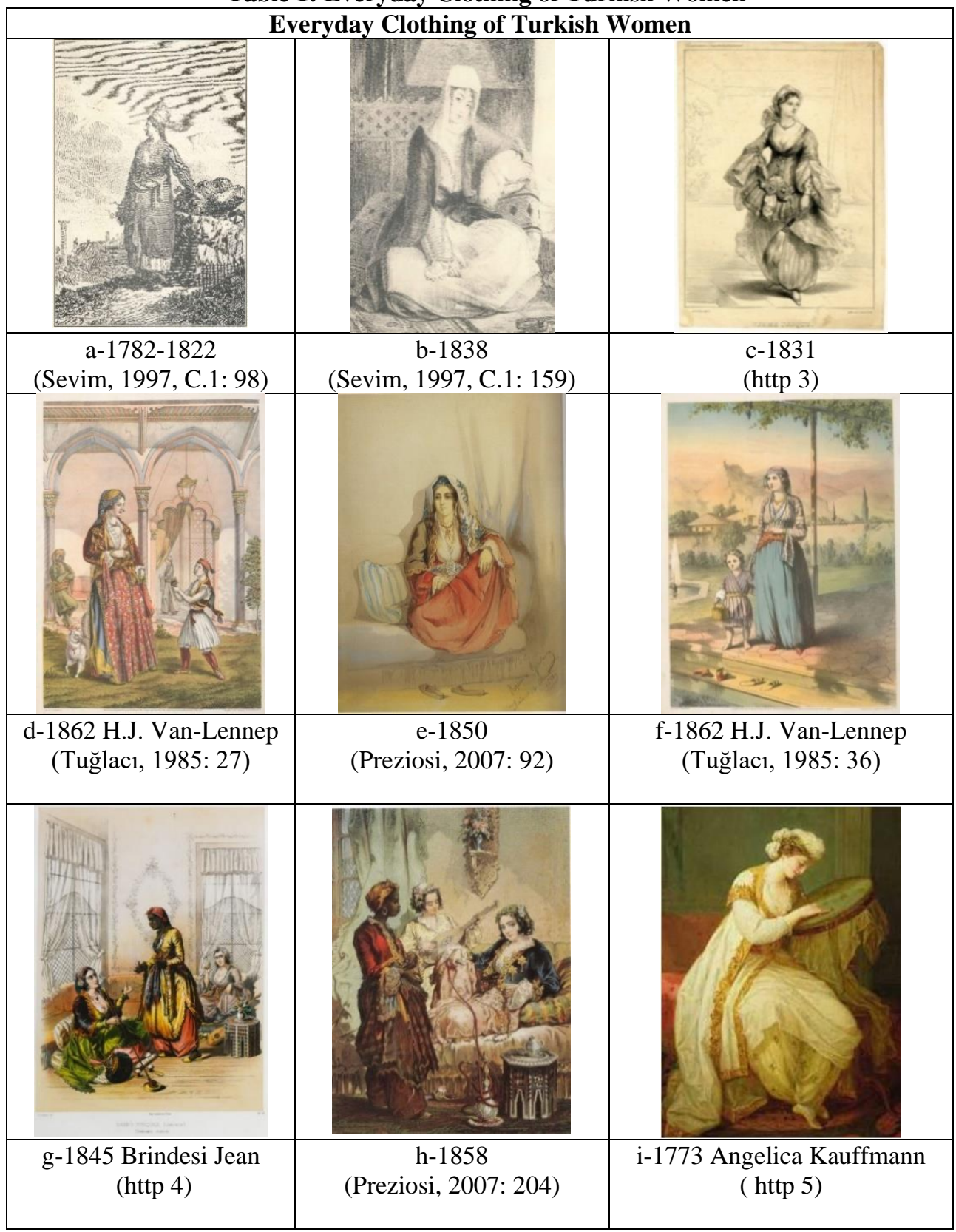


All the images in Table 1 show women wearing the şalvar with a gown, with some women wearing a gown on top of a shift or undershirt. All the gowns in the images are long and open in the front, with v-necks and deep slits at the sides of the hem. The wide neckline is covered up by the camisole or shift worn under the gown. The gown sleeves may be tight or loose, but usually have slits, and are long enough to cover the hands. The sleeves of the undershirt or shift can be seen underneath loose sleeves with slits. Due to their shape, gowns are comfortable and thus essential, often-used indoor clothes. Bayer (2010:87 states that gowns are the ideal indoor garments for sitting on divans, while also being the second layer of clothing used outdoors, over the şalvar and thin linen shirt.

In the images a, d, and $\mathrm{i}$, the outer gown worn on top of a shift and an inner gown can be interpreted as a reflection of the layered clothing characteristic. It is worth noting that while the outer gowns are of different colors such as red, green and pink, with various patterns such as plain, striped and with patterned weaves, the shifts worn within are uniformly cream-colored. The shifts worn next to the skin in Turkish clothing are generally made from cloth in the natural color of cotton or silk. The shifts in black-and-white images are also lightcolored. In their study on the göynek, Koca and Vural (2013: 276) state that women in Anatolia wore silk, cotton or linen göyneks (shifts) in the natural cream color of the fibers underneath their clothes, next to the skin and usually above the şalvar. They also explain that this cloth was woven as a very narrow piece of fabric due to the size of the hand looms they were produced on, which played an active role in forming the shapes of the shifts.

The images by Lennep and Preziosi $(d, e)$ show red and gold embroidery on women's clothes. It is thought that the color red, which is always flamboyant and ostentatious, was often preferred by Turkish women who loved show and splendor. In his work titled "An Essay on Clothing in Divan Poetry," Öztoprak (2010: 105) stated the most common color of Ottoman clothes to be red, followed by green, blue, yellow, white, and black, based on the couplets he studied. His statement also appears to support this idea. It is noteworthy that black is not used in the images of women's clothing in Table 1. This calls to mind Gürtuna's statement (2002: 1777) that "Muslims did not like to wear black because Christians wore clothing in this color frequently."

The belts and sashes that women tied around their waists on top of their gowns are important items of clothing complementing Turkish women's outfits. Gürtuna (2002: 1777) states that Turkish women tied broad sashes of silk or linen around their waists two or three times, or that they wore thin belts with gold or silver buckles. This corresponds to the visuals and interpretations in Table 1.

Although the images $\mathrm{a}, \mathrm{b}$, and $\mathrm{f}$ in Table 1 have simple and artless features compared to other images, it is seen that the Turkish clothing style shows the 
characteristics of layered clothing, which produces a rich image. The sash tied around the waist as the uppermost layer of clothing is a remarkable detail. The sash is one of the most important items of old Turkish clothing: wrapped around the waist on top of other clothing, it is not only a decorative item, but also a highly functional and personally variable piece of clothing that allows carrying many objects between its folds (Koçu, 1967: 161; Özlük, 2011: 109). The belts in the visuals are plain and flat, which indicates that they may be used for functional purposes, rather than for decorative purposes, and hence, that these images are thought to be images of Turkish women living in rural areas. Although the belt and sash may be regarded as clothing elements that perform the same function, a slight difference in the usage areas is significant. Sashes are usually used in everyday wear, while belts are used with more exclusive clothes, hence they also give clues about the status of women. It is thought that the women in the other images are wealthier women living in the city or in mansions, considering that they wear short vests with embroidery on the sleeves, collars and hems. This interpretation s based on the fact that the status-determining characteristic of clothes was very widespread in the Ottoman society, and that people's professions, authority, belief, or social standing were often reflected in their clothing. In her letters, Lady Montegu 's mentions that "Here is a fellow that carries embroidered handkerchiefs upon his back to sell, as miserable a figure as you may suppose such a mean dealer, yet I'll assure you his wife scorns to wear anything less than cloth of gold, has her ermine furs and a very handsome set of jewels for her head" and also describes other instances which show the splendor of clothing (Özlük, 2012: 152; Montegue, 1993: 134).

The women in the images in Table 1 wear different types of headdresses: the fes, tepelik, and hotoz, as well as headscarves. The women in images a and $\mathrm{b}$ wear types of hotoz higher than those in the other images. The women in the visuals $\mathrm{d}$ and $\mathrm{f}$ wear the tepelik, while the woman in image e wears the fes and the women in the other images wear scarves tied in different styles. Since all women are shown indoors, these are probably different styles to leave part of the hair exposed. According to Koçu (1967: 113), the fez, a red cap, was also used by women in Ottoman society, and like with other headdresses, was covered or tied around with a scarf.

Headwear was very important in the Ottoman Empire. No one walked around bare-headed, either indoors or outdoors, as this would have been considered a major mistake. In addition, in the Ottoman Empire headwear in men and women was also used as an important means of determining status (Tezcan, 2006: 185). Considering that in the clothing of Turkish women, head coverings were both a status indicator and used for veiling purposes, and that Turkish women in Ottoman society were fond of new and different styles of 
clothing, it is possible to say that headwear changed frequently over the centuries.

It is seen that the women pictured indoors in the color images wear slippers in yellow hues, while the woman in image f, pictured outdoors, wears red shoes. Menavino, who gives information about the women's indoor clothing in the $16^{\text {th }}$ century, suggests that women wore very stylish Damascus-made shoes, of leather in coral and other colors and embroidered with gold or silver thread (Gürtuna, 2002: 1779). Menavio's descriptions, however, refer to the clothing of the $16^{\text {th }}$ century. German marshal Helmuth von Moltke, who lived in Istanbul between 1835 and 1839, stated that Turkish women wore yellow shoes outdoors (Koç \& Koca, 2010: 45). Image f is from 1862 and is found in the Eastern Album by Lennep. Since Menavio's description covers indoor clothing and Lennep's image also reflects indoor clothing, it can be said that the limitation of color in outdoor footwear does not apply to indoor footwear.

Image $\mathrm{c}$ of Table 1 appears to be different from the others, with a loose şalvar, long-sleeved shirt and shift, and a short-sleeved gown on top. The difference is created by the wide and slit sleeves of the shift visible under the short sleeves of the gown, the large buckles of the belt, and the ruffled hem of the gown. However, the tight and gathered hem of the gown does not conform to the usual shape of women's gowns. This is interpreted as the effect of Western-style clothing, due to the European painter adding his own interpretation. Koç (2009: 95-98) states that the gowns worn by Turks were usually in geometric shapes, cut simply rather than elaborately, since the width of the fabric was narrow and the fabrics were very valuable. He also points out that the gowns usually have a crew, scoop or v-neck, and that the sleeves of shifts are longer than those of the gowns and peep out from beneath the gowns. According to Koç, gown cuts were diversified from the beginning of the $18^{\text {th }}$ century onwards, with details like cuff cuts and tightly fitting bodices, and that şalvars gradually became looser, whereas the hems were raised to above the ankles towards the mid- $18^{\text {th }}$ century, necklines dropped to reveal the breasts, and envelop cuts became the fashion in the front of the hems of gowns.

Gahramanl1 (2012: 246) states that with the "Tulip Period" (1718-1730) and the imperial edict of Gülhane (1839), women became acquainted with European fashions, and began moving away from traditional clothing styles. According to Gahramanl, by the end of the 18th and the beginning of the 19th century, women began following the Parisian fashions they saw in magazines, and having the gowns they found in these magazines made in dressmaking shops. The statements in his conclusion about women influenced by the European fashion wearing the corsets they saw in the fashion magazines and the corset fashion spreading rapidly support the interpretation that the women's clothing seen in Table 1c is influenced by western fashion. It can also be said that the jewelry around the woman's neck as well as the belt around her waist 
reflect her social standing. Özlük (2011: 108) notes that the belt was a sign of wealth in Ottoman society that belts made of gold and silver, sometimes made with precious stones, were common, the decorative elements that complemented the clothes had a role in determining social status. In a 1718 letter, Montagu (2008: 98-99; http 2) describes her impressions of women's clothes seen during a visit to Hafize Sultan in great detail and concludes, "This I am very sure of, that no European queen has half the quantity and the Empress's jewels, though very fine, would look very mean near hers." This gives an indication of the fondness of Turkish women for jewelry and precious stones.

The women in images $\mathrm{g}$ and $\mathrm{h}$ in Table $1 \mathrm{can}$ be assumed to be of high social standing, possibly the wives of men of high status, judging by the positions in which they sit, and the splendor of their own clothing and that of the servants around them: the women in the visuals appear quite similar to those encountered by Lady Montagu when visiting the wife of Kabya Mehmet Aga, and described in her letters:

On a sofa raised three steps and covered with fine Persian carpets, sat the Kabya's lady, leaning on cushions of white satin, embroidered, and at her feet sat two young girls, the eldest about twelve year old, lovely as angels, dressed perfectly rich, and almost covered with jewels. But they were hardly seen near the fair Fatima (for that is her name) so much her beauty effaced everything I have seen all that has been called lovely either in England or Germany and must own that I never saw anything so gloriously beautiful, nor can I recollect a face that would have been taken notice of near hers. ... She was dressed in a caftan of gold brocade, flowered with silver, very well fitted to her shape, and showing to advantage the beauty of her bosom, only shaded by the thin gauze of her shift. Her drawers were pale pink, her waistcoat green and silver, her slippers white, finely embroidered, her lovely arms adorned with bracelets of diamonds and her broad girdle set round with diamonds; upon her head a rich Turkish handkerchief of pink and silver, her own fine black hair hanging a great length in various tresses, and on one side of her head some bodkins of jewels (Bayer, 2010: 38; http 1)

Judging from the images in Table 1 and the interpretations of these, it is possible to say that the clothing of Turkish women mostly kept its traditional form, though with small changes, until the end of the 18th century. However, as a result of the increase of relations with Europe with the beginning of the 19th century, Western influences appeared in fashion as in every other arena, and changes in clothing began to manifest. 


\subsection{Everyday Clothing of Armenian Women}

There was no unity in the religious and ethnic structure of the Ottoman Empire as in the case of some other empires. This unique characteristic seen in the general structure of the Ottoman Empire was also the case in city life. Many Ottoman cities were quite complex in terms of language, religion and ethnicity (Kara, 2012: 307). Under the Ottoman State administration, Turks and Armenians coexisted peacefully for a long time, and as a result of social interactions naturally came interacted culturally (Şahin, 2005: 209).

After the Ottoman Empire conquered Eastern Anatolia and the Caucasus during the Yavuz and Kanuni periods, many of the Armenians settled in Istanbul (Ceco, 2013: 83). The Armenians lived a comfortable and peaceful life in the Ottoman State. They served as civil servants in various positions, and did not encounter any problems with the Turkish people in social life. Sources also mention that Armenians and Turks reached out to each other on special occasions like holidays (Arisan and Güney, 2000: 273). The cultural interaction and sharing that arise as a result of these contacts and common living spaces also manifest themselves in different social areas. But as far as clothing, one of the most important elements of cultural interaction in close contact, is concerned, it is also an indisputable fact that, like other peoples, the Armenian people were obliged to comply with the rules imposed by the decrees concerning clothing.

In traditional life, clothing can be restricted by religious rules and influenced by geographical conditions, customs, traditions or various ethnic origins, peoples and groups. Through the interactions of the various communities, the Armenians living in the Ottoman State became part of a whole that formed the Ottoman Empire from their traditions to their clothing styles, language and everyday life (Şahin, 2005: 209). In the Ottoman social life, the color, style and form of clothing was regulated by certain rules and practices, taking into account differences such as whether the wearer was Muslim or non-Muslim, male or female, and from the upper or lower class.

An examination of the restrictions on clothing in the Ottoman state reveals that these restrictions were mostly aimed at differentiating the Muslim and non-Muslim people from each other. Ercan (2001: 180) states that nonMuslims were banned from wearing the clothes belonging to Muslims by decree and vice versa which leads him to conclude that the two communities were in fact equal. Koç and Koca (2010: 45) state that these prohibitions were not limited to clothes only, but applied even to the color of shoes. Pointing out that the German Marshal Helmuth von Moltke, who was in Istanbul between 1835 and 1839, drew attention to the fact that Turkish women wore yellow shoes while Armenians wore red, Greeks wore black and Jews wore blue shoes, the authors emphasize the prohibitions on clothing in the Ottoman Empire. Dalyan (2011: 95) states that women preferred brighter, more vibrant 
colors in the inner regions and that in 1854 women favored red, blue and bright white over all other colors.

Table 2. Everyday Clothing of Armenian Women

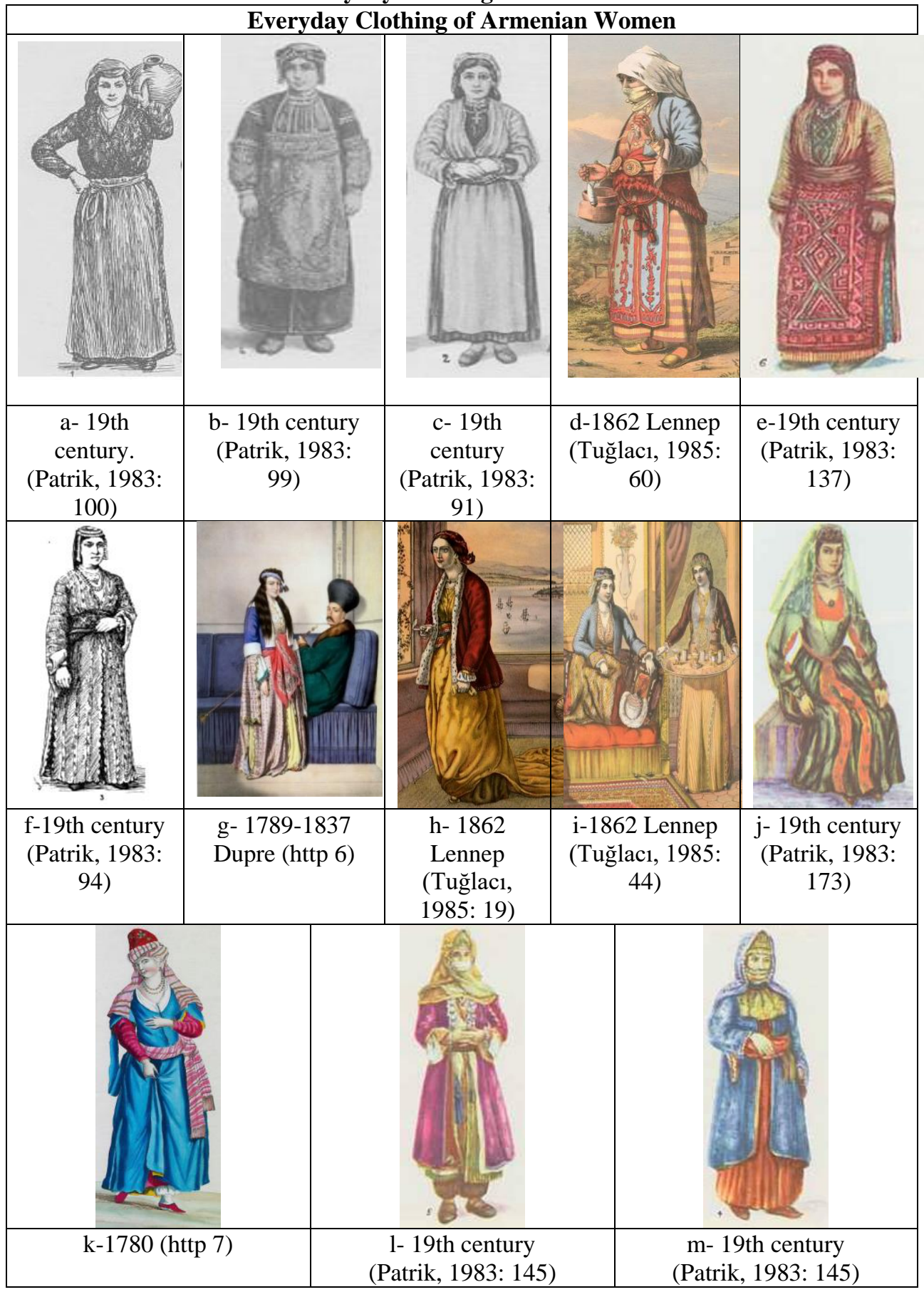


Images a, b, c, d, e of Table 2 show women to be wearing long shifts and şalvar underneath their gowns. It is noteworthy that gowns are worn in all images in this table. Although not visible due to the long skirts in the other images, the women are wearing long şalvar on the lower body and shifts underneath gowns on the upper body, the bodices coming down to waist and hip level. The light-colored shift visible underneath the V-collar or frontfastening gown looks same as the gowns of the Turkish women.

The long aprons (a, b, c, d, e) that women wear tied around the waist are a remarkable feature in the other images. Clues like the aprons, items like pitchers and buckets carried in the hands, sleeve protectors on the arms (b) and sashes around the waist $(\mathrm{c}, \mathrm{d}, \mathrm{e})$ indicate that the women in these images are women living in rural areas, wearing everyday clothing. the fact that the women in the other images wear no aprons and are dressed more elaborately confirms this idea. The usage and patterns of the aprons and sashes indicate that they are made of home-spun wool. Tuğlacı (1985: 127) states that Henry John Van Lennep, traveler and missionary born 1815 in İzmir, pointed out in his 1862 Oriental Album that Armenians usually made the clothes of the household members from home-spun wool, which further confirms this assumption.

According to Matossian and Villa (2012: 86) "in Anatolia, Armenian women wore shifts, şalvar and gowns on top and tied aprons around their waists. Married women wore headscarves, but did not cover the lower part of the face." This also corroborates the interpretation above. Since many sources indicate that married Armenian women wore headscarves, it would be reasonable to assume the women in these images to be married. The fact that the headscarves lack ornamentation, taken together with the style of clothing, indicates that the women in these images (a, b, c, d, e) are Armenian women living in rural areas who also deal with work outside the home.

In 1901, Lynch visited Kemerli/Kamarlı near Yerevan and saw that women still wore caps and covered their heads and faces with white cotton headscarves. Boğos Natanyan, on the other hand, states that women covering their heads and hiding their hair is a completely ancient Armenian tradition. In cities like Van in Eastern Anatolia, married women covered their heads as well as their faces, to above the nose. But single girls were exempt from this practice at home and in the family. With the fez beginning to be worn in public spaces during the reign of Mahmut II, Armenian woman started to wear this cap covered with white cotton headscarves (Dalyan, 2011: 95).

The clothing of Armenian women and the items making up this form vary according to the status of the woman. This is clearly observed in the images $f$, $\mathrm{g}, \mathrm{h}, \mathrm{i}, \mathrm{j}, \mathrm{k}, \mathrm{l}$ and $\mathrm{m}$ in Table 2 . The lack of aprons worn by the women in these images, the ornamental rather than functional look of the belts, the fabric of clothing items and the number of embellishments on their clothes, as well as 
the details of their headdresses and their ornaments indicate that the women in these images are urban women of high social status, pictured indoors. The valuable fabrics used in the garments, the fur used in some parts of the garment such as the collar and cuffs, the abundance of embellishments and embroidery as well as the jewelry reflect the economic and social status of the women. Matossian and Villa (2012: 85) point out that Armenian women wore caps shaped like truncated cones and covered their hair and the part of the face below the nose with scarves, and that the use of fur in their clothes was an indicator of wealth. Using Lasitsyan's description, the authors also state that women often wore red, believing it to dispel bad luck, and that they wore loose shifts and şalvar as underwear.

Lennep (Tuğlac1, 1985: 105) described urban Armenian women's clothing as follows: "the garments, made of brightly colored, striped or flowered pure silk, are worn crossed over the chest and are divided into three parts from the bottom of the belt or girdle, and the lengths vary according to fashion." Lennep's descriptions matches the form of the three-skirted gown and with the gowns in the images. Şehsuvaroğlu (1999: 197-200) comments that "Armenian women wear skirts on top of their trousers, but cover their faces with beautiful, white tulle instead of a veil of black cloth," describing the şalvar and the yaşmak. This description supports the interpretations of the garments in Table 2.

In some of the images in Table $2(1, \mathrm{~m})$, the woman wears a shorter garment on top of the gown. The use of the yaşmak with this garment indicates that this garment is a piece of outerwear, worn outdoors. While this garment is thought to be the arkhaluk, the different shape of the collar feature creates contradictions. Matossian and Villa (2012: 85) state that Armenian women in Caucasia wore the arkhaluk (arkalık) like men, and clarify that this garment is a long coat peculiar to Caucasian people, descending to knee level, with a stiff, closed collar and small buttons from collar to hem, usually worn on top of a shirt and with a sash. The garments in some images $(\mathrm{h}, \mathrm{i}, \mathrm{m})$ are not fastened in the front and have varieties of collar shapes. This could be a reflection of the influence of Western clothing styles on the clothing of the period, which would also account for the differences in the arkhaluk.

The skirt worn by the woman in image h of Table 2, cut tight to the waist and with gathered hems, differs from the others and again reflects influences of the Western style. Koçu (1967: 169) states this situation to be linked to nonMuslims, who, due to modernization and Westernization, were keen on conforming to European clothing styles and pioneers in this regard, losing their sensitivity to boundaries regarding clothing. He points out that at the ball in honor of victory in the French embassy after the Crimean victory in 1855 , Greek and Armenian ladies of Istanbul wore the garment named "malakof", and that Turkish ladies wore the same garment under the name of "sepetli 
fistan" (basket gown). This is actually the name given in Istanbul to a ball gown fashionable in France during the Second Empire (1854-1855), with the characteristic features of a small waist and wide hoop skirt, making it look like an inverted basket.

Regarding image i of in Table 2, from Lennep's Oriental Album, Lennep stated that these clothes had been undergoing small changes through the years, but that they were still the same clothes worn in Ninova, the old national clothes. According to Lennep, a red cap with a large blue tassel hanging down to the shoulders is placed on the head. The edge of the crown is decorated with gold coins and precious stones, a handkerchief is wrapped around the head, and sometimes jewels or pearls is placed on it. The gown, open on both sides under the sash, is floor-length. The sleeves are long and hang down in the old style. This long sleeve was later replaced with a shorter one. The jacket is usually embroidered with golden yarn (Tuğlacı, 1985: 118).

In order to determine boundaries between religious groups, symbolic colors were used as well as clothes. Krafft, who visited the Ottoman territories in 1574, states that he was required to wear a cap with red and blue stripes as worn by Christians, which Armenians, belonging to the same religion, also had to wear (Bozkurt, 2014: 24). A decree by Selim II, released on 1 August 1568; outlined that besides other rules, Armenian women (as distinct from Jewish women) had to wear red and yellow striped scarves around the head, and that non-Muslims were not allowed to wear high-quality clothing (Ercan, 2001: 182). Dalyan (2011: 95) states that Armenian women who lived in Trabzon covered their heads with a bright red headscarf, and that this tradition continued for a long time, especially in provinces and inland areas. Judging from these examples, it is possible to say that headwear, ornaments and colors were important in distinguishing ethnic differences.

Bozkurt (2014: 26) states that in the clothing of non-Muslims, sky-blue, navy blue, gray, black, red and yellow colors were predominant. He draws attention to the importance of the colors of clothing in social life, pointing out that most of these colors are associated with mourning in Islamic culture. Bağc1 also agrees, stating that in funeral-themed miniatures, black, navy, sky blue, green and gray clothes predominate.

It can be said that the color factor of the Armenian women's footwear is important, as it is in the case of clothes, and that it varies according to the usage and the status of the wearer. Akçam (1994: 89-91) points out that non-Muslims were not allowed to have the same clothes, headwear, animals etc. as Muslims, and that Armenians had to wear red hats and shoes, whereas Greeks had to wear black and Jewish people blue ones. In his travel book, Tavernier (2006: 255-257) states that Armenians hated indigo blue, because they believed that this color was cursed by God. 
The images show the Armenian women to be wearing slippers indoors and flat-heeled shoes outdoors, similar to those described by Lennep (Tuğlac1, 1985: 136): "women wear shoes of thin leather with soles made of the same material. When leaving the room, they are worn with thick-bottomed slippers." Ercan (1990: 120) points out that non-Muslim women were not allowed to wear the ferace and the başmak and thus wore heeled shoes or şirvani instead of the latter, and that Armenian women wore leather bootees and şirvani başmak, the başmak being a type of unlined, flat-heeled shoe made of black leather. Regarding the footwear, Lennep (Tuğlacı, 1985: 105) also states that the slippers worn indoors were often finely and elegantly embroidered with gold or silver threads on red, blue or white satin. He also mentions that Armenian women wore jewels on their necks, their wrists, their fingers and their ears, and that on special days and occasions they also wore jewels on their heads.

In his work titled "Inheritances of Armenian Women," Akyüz (2007: 463) interprets sixteen inheritances recorded in Ankara in the $18^{\text {th }}$ century as belonging to Armenian women. He mentions that among these inheritances belonging to women, the most striking objects are jewelry and items of clothing, the most valuable of these being jewelry made of silver, gold and pearls. He points out that these jewels signify both wealth and elegance.

The result of the analysis of the images in Table 2 reflecting the everyday clothing of the Armenian women shows that everyday clothing items were found to be composed of the şalvar, a shift, a three-skirt gown and bodices in various lengths. While Armenian and Turkish women can be stated to dress similarly because of the layered clothing style, the form of the clothing and the order in which items were put on, the colors of the garments can be said to be the most important indicators of the differences between the two communities.

\section{Conclusion and Discussion}

The everyday clothing types of Turkish and Armenian women examined separately in Table 1 and 2 were found to have differences in color and small details, although they were similar in usage, garment types, color and form. The similarities and differences between the two types of clothing, together with explanations as to the specific detail and location of the differences and similarities, are shown in Table 3. 
Table 3. Everyday clothing of Turkish and Armenian women compared

\begin{tabular}{|c|c|c|c|c|}
\hline \multirow[t]{4}{*}{ Options } & \multicolumn{2}{|c|}{ Turkish } & \multicolumn{2}{|c|}{ Armenian } \\
\hline & $\begin{array}{c}18 \text { th } \\
\text { century }\end{array}$ & 19th century & 18th century & 19th century \\
\hline & $\frac{a}{a}$ & $\frac{\left(\int^{(x)}\right.}{b}$ & A & 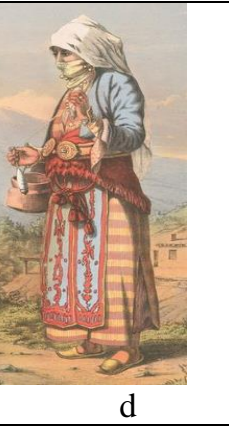 \\
\hline & $\begin{array}{c}1782- \\
1822 \\
\text { C. } \\
\text { Gouffier }\end{array}$ & $\begin{array}{c}1862 \text { H.J. } \\
\text { Van Lennep }\end{array}$ & $\begin{array}{c}1780 \\
\text { (http7) }\end{array}$ & 1862 Lennep \\
\hline $\begin{array}{l}\text { Outer garment/ } \\
\text { Silhouette }\end{array}$ & Gown & Gown & Gown & Gown \\
\hline Sleeve & Long & Long & Short & Long \\
\hline Collar & $\mathrm{V}$ & $\mathrm{V}$ & Scoop & $\mathrm{V}$ \\
\hline Color & & Red/blue & Red/blue & Red/blue \\
\hline Embellishments & No & Yes & No & Yes \\
\hline Headdress & Cap & Cap & Cap & Scarf \\
\hline Shoe shape & Round & & Pointed & Round \\
\hline Shoe color & & & Red & Yellow \\
\hline
\end{tabular}

All the images in Table 3, feature layered clothing. The ankle-length outer garment in gown or "entari" form has the same style in both communities. Women wear the şalvar, a shift and a gown, with bodices ending at waist or hip length. Gowns are open in the front, with deep slits up to the waist on the sides. The two front parts are folded over and tied down with belts or sashes. This is similar to the three-skirted gown, one of the most important garments of Turkish folk dress.

Sleeves are similar in $\mathrm{a}, \mathrm{b}$ and $\mathrm{d}$. Similarly, the V-neck is commonly used (a, b, d). the Armenian woman of the $18^{\text {th }}$ century wears a deep scoop neck, with her cleavage covered up by the V-neck shift worn within. All images feature both inner and outer gowns, although short sleeves of the Armenian woman in c show the longer sleeves of the gown worn within. These characteristics of usage in the collar and sleeves also seen in Levni's paintings of Turkish women, suggesting, together with other similarities, that communities with different cultures living in the same society are influenced by each other in the area of clothing as in other instances.

Garnett (2009: 143) points out that the clothing of the Armenian women in Van is similar to the clothes worn by all Ottoman women, in many parts of 
the empire, which supports these findings. He emphasizes the multicolored scarves wrapped around the $f e z$ in the shape of a turban as an important characteristic of the clothing of the Armenian women in Van. He describes the garments worn by these women as the long, tight cotton gown, or entari, the şalvar made of colored silk, tightening toward the ankles, and the şapo, an ankle-length, loose, sleeveless gown slit to the waist on the sides. The front of the şapo and the cleft hem of the gown are decorated with lace. The cübbe, a fur-hemmed loose coat revealing the cuffs, is also worn.

While the clothes of the women in the images in Table 3 share similarities, their headdresses are different from one another. Bearing in mind that headwear has an important place in the clothing culture of the Ottoman state and is used as a determinant of status, the fact that headdresses show differences in different communities is considered a natural result of this. Koca (2009: 67) points out that within the multinational state of the Ottoman Empire, headwear clearly reveals the rank, class and title of everyone, emphasizing the importance and function of headwear. Thus the differences in headwear, unaffected by cultural interaction, are an expected result, though small similarities in details and embellishments can sometimes be observed. For example, caps of various sizes similar to the $f e z$, with scarves wrapped around them, are worn by women of both communities.

All women in the images wear sashes. Although there are differences in the folding and tying styles, sashes are seen to be a complementary element that is common to both communities, and shows similarities. The Turkish women $(\mathrm{a}, \mathrm{b})$ and Armenian women $(\mathrm{c}, \mathrm{d})$ in the images have sashes around the waist, on top of the outer gown.

The images of the Turkish woman in $b$ and the Armenian woman in $d$ are from the same period, and both women are seen to be wearing clothes with embellishments in the form of embroidery. This suggests that embroidery is a type of embellishment that is typical for the period and favored by both communities.

Paintings and engravings are among the most valuable resources prepared or commissioned by foreign travelers visiting the Ottoman Empire. There are many paintings and engravings portraying the daily life of the peoples living within the borders of the Ottoman Empire, with a significant number among them revealing clues about clothing. Each garment is valuable as an item of material culture and is a document of the cultural history of societies, now as in the past. This shows that it is very important for experts to interpret these items as they were portrayed in the past. Hence similar studies of images in archives should be promoted and encouraged. 


\section{References:}

1. Akçam, T. (1994). İslam'da hoşgörü ve sınırl, Ankara: Başak Publications.

2. Akyüz, J. (2007). Ermeni kadinlarına ait terekeler. Hoşgörü toplumunda ermeniler, Cilt II. Erciyes Üniversitesi I. Uluslararas1 Sosyal Araştırmalar Sempozyumu.

3. Arısan, K. \& Güney, D. (2000). Abdulaziz Bey, Osmanlı Adet, Merasim ve Tabirleri, Istanbul: Tarih Vakfi Yurt Publications

4. Barbarosoğlu, F (2013). Moda ve zihniyet, 6. Bask1. İstanbul: İz Publications.

5. Bayer, F. (2010). Osmanlı kadınının giyim kuşamı (Tanzimat'tan Meşrutiyete), graduate thesis, Erciyes University, Institute of Social Sciences, Kayseri.

6. Bozkurt, Ö. F. (2014). Osmanlı İmparatorluğu'nda gayrimüslimlerin klyafet düzenlemeleri (XVI - XVII. Yüzylllar), graduate thesis, Hacettepe University, Institute of Social Sciences, Ankara.

7. Ceco, S. (2013). Lale devri ressamı Van Mour' un çizimleriyle osmanlılar klyafet albümü, İstanbul: İstanbul Büyükşehir Belediyesi Kültür Publications.

8. Dalyan, M. G. (2011). XIX. yüzyılda gelenekten batı kültürüne geçişte ermeni yaşamı, Ankara: Öncü Printing house.

9. Ercan, Y. (1990). Osmanlı imparatorluğunda gayrimüslimlerin giyim, mesken ve davranış hukuku, Ankara Üniversitesi Dergiler Veritabanı 1 .

10. Ercan, Y. (2001). Osmanll yönetiminde gayrimüslimler. Kuruluştan Tanzimat'a kadar sosyal ekonomik ve hukuki durumlarl, Ankara: Turhan Bookstore.

11. Gahramanl1, N. (2012). Servet-i fünûn romanlarında devrin moda olgusunun kadın kıyafetine etkisi, Uluslararası Sosyal Araştırmalar Dergisi, 5(23), 5- 23.

12. Garnett, L. M. J. (2009). Türkiye'nin kadınlart ve folklorik özellikleri, 1. Baskı. Istanbul:Oğlak Publications.

13. Gürer, S. (2010). XVII-XVIII ve XIX. yüzyıllarda fransız seyahatnamelerinde osmanl toplumu, doktora tezi, Ankara Üniversitesi, Sosyal Bilimler Enstitüsü, Ankara.

14. Gürtuna, S. (2002). Klasik dönemde osmanlı kadınının giyim tarzı. Ankara: Yeni Türkiye Publications.

15. http1:

http://www.swansea.ac.uk/visualanthropology/projects/004_Montagu/ turkishEmbassyLettersTheLetters.htm.

16. http2: 
https://quod.lib.umich.edu/e/eebo/A07834.0001.001/1:44?rgn=div1;vi ew=fulltext

17. http 3:

British Museum (Museum Number: 1871,1209.3095)

http://www.britishmuseum.org/research/collection_online/collection_ object_details.aspx ?objectId $=1607712 \&$ partId $=1 \&$ searchText $=$ Museu $\mathrm{m}+$ Number: $+1871,1209.3095 \&$ images $=$ true \&ethname $=6961 \& \mathrm{museu}$ mno $=1871,1209.3095 \&$ page $=1$

18. http 4:

http://eng.travelogues.gr/item.php?view=54888

19. http 5:

Pushkin State Museum Of Fine Arts, Moscow https://www.alinari.it/en

20. http 6:

http://tr.travelogues.gr/item.php?view $=40733$

21. http 7:

http://eng.travelogues.gr/item.php?view=59692

22. Kara, A. (2012). XIX yüzyılda osmanlı anadolusunda ermeni toplum yaşantıs1: Çorum ve Antakya karşılaştırmalı örnekleri. International Journal of Social Science, 5(6), 303-311.

23. Karasar, N. (2007). Bilimsel araştırma yöntemi, 17.Basım. Ankara:Nobel Akademik Yayıncılık Eğitim Danışmanlık.

24. Koca E. (2009). 18. ve 19.yüzyıl osmanlı erkek modas1. Türk-İslam Medeniyeti Akademik Araştırmalar Dergisi, (7), 63-81.

25. Koca, E. \& Koç, F. (2013). 19. yy osmanl gezici esnaflarının giyim kuşam özellikleri. Uluslararası Türk ve Dünya Kültüründe Kahramanmaraş Sempozyum Bildirilerinde sunuldu, Kahramanmaraş.

26. Koca, E. \& Koç, F. (2014). Kıyafetnameler ve Ralamb'ın kıyafet albümündeki 17. yüzyıl osmanlı toplumu giysi özelliklerinin incetlenmesi. Turkish Studies, 9(11), 371-394.

27. Koca, E. \& Vural, T. (2013). Türk halk giyim kuşamında kullanılan göynekler. 7. Uluslar Arası Türk Kültürü Sanatı ve Kültürel Mirası Koruma Sempozyumu/ Sanat Etkinlikleri, Bakü:Azerbaycan 275-284.

28. Koç, F. \& Koca E. (2012). The clothing culture of the Turks, and the entari. Folk Life: Journal of Ethnological Studies, 50(2), 141-168.

29. Koç, F. \& Koca, E. (2010). Osmanlı kanunlarında giyim- kuşam yasakları. Türk- Islam Medeniyeti Akademik Araştırmalar Dergisi Uluslararası Hakemli Dergi, , 10(31-50).

30. Koç, F. \& Saatçioğlu, K. (2016). Türkiye'den Yunanistan'a göç eden ortodoks rum mübadillerin giyim-kuşam özellikleri. II. Uluslararas1 Sanat ve Tasarım Kongresi, 9 Eylül Üniversitesi, Güzel Sanatlar Fakültesi, İzmir. 
31. Koç, F. (2009). 18. yüzyıl minyatür sanatında osmanlı kadın modası. Türk- Íslam Medeniyeti Akademik Araştırmalar Dergisi Uluslararası Hakemli Dergi, 7, 82-98.

32. Koç, F., Koca, E. \& Vural, T. (2015). Türk kültüründe gelin ve damat (güvey) giyimi. Türkiye Cumhuriyeti Aile ve Sosyal Politikalar Bakanlığı Aile Yazıları, 8. Ankara: Başak Press

33. Koçu, R. E. (1967). Türk giyim kuşam ve süslenme sözlüğü, I. Basım. Ankara: Sümerbank Kültür Publications.Başnur Press.

34. Matossian, K. M. \& Villa, H. S. (2012). Alintılar ve fotoğraflarla 1914 öncesi ermeni köy hayatı, İstanbul:Aras Publications.

35. Meriç, N. (2005). Adab-ı muaşeret: Osmanlı' da gündelik hayatın değişimi (1894-1927), İstanbul: Kap1 Publications.

36. Montagu, L. (2008). Şark mektupları, İstanbul: Antik kitap, XLI.

37. Montagu, L. M.W. (1993). Turkish embassy letters. XLVIII (Pera, Constantinople, May 1718), To the Countess of 253.

38. Moryson, F. (1617). Containing his ten yeeres travell throvgh the twelve domjnions of Germany, Bohmerland, Sweitzerland, Netherland, Denmarke, Poland, Jtaly, Turky, France, England, Scotland, and Ireland, The Discovrse Vpon Severall Heads Throvgh The Said Severall Dominions. Of Trauelling In Generall. Part Iii. The Fourth Booke, 176.

39. Ozell, J. (2014). A voyage into the levant, Joseph Pitton de Tournefort, trans. John Ozell, Cambridge University Press. https://books.google.co.uk/books?id=FWgZAwAAQBAJ\&printsec $=\mathrm{f}$ rontcover\&hl $=$ tr\&source $=g b s \_g e \_s u m m a r y \_r \& c a d=0 \# v=$ onepage $\& q$ $\& \mathrm{f}=$ false]

40. Özlük, I.P (2011). Edirneli Nazmî’nin Türkî-İ basit Divanı'nda giyim unsurları. Sosyal Bilimler, 1(2).

41. Özlük, I.P. (2012). 21. yüzyılda eğitim ve toplum, Lale Devri'nde kadın giyimi. Eğitim Bilimleri Ve Sosyal Araştırmalar Dergisi, 1(1), 147-162.

42. Öztoprak, N. (2010). Divan şiirinde giyim kuşam üzerine bir deneme. Divan Edebiyatı Araştırmaları Dergisi, 4, 103-154.

43. Refik, A. (1998). Kafes ve ferace devrinde İstanbul, (Eds. T. Yücel) İstanbul: Umut Press.

44. Şahin, G. (2005). Amerikalı bir misyonerin XIX. yüzyılın ortalarında Türk-Ermeni kültürel ilişkileri ile ilgili izlenimleri üzerine bir değerlendirme. Afyon Kocatepe Üniversitesi Sosyal Bilimler Enstitüsü Dergisi, 7(1), 208-239.

45. Şehsuvaroğlu, H. (1999). İstanbul'dan sesler ve renkler, Istanbul: Türkiye Sınai Kalkınma Bankası Publications 
46. Tavernier, J.B. (2006). Tavernier seyahatnamesi, (Eds. S. Yerasimos, Çev. T. Tunçdoğan) İstanbul: Kitap Bookstore.

47. Tezcan, H. (2006). Osmanlı sarayının çocukları, şehzadeler ve hanım sultanların yaşamları ve giysileri. İstanbul: Aygaz, Mas Printing.

48. Tezcan, M. (1983). Giyim olgusuna sosyo-kültürel bakış ve türklerde giyim. Ankara Üniversitesi Eğitim Bilimleri Fakültesi Dergisi, 16(1).

49. Tuğlacı, P. (1985). The oriental album. Twenty illustrations in oil colors of the people and scenery of Turkey, with an explanatory and descriptive by Henry J. Van Lennep. İstanbul: Altayhan Press.

50. Wortley-Montagu, L.M. (1993). Turkish embassy letters. Introduced by Anita Desai, Text edited and annotated by Malcolm Jack. William Pickering. London.

51. Yıldırım, A. \& Şimşek, H. (2008). Sosyal bilimlerde nitel araştırma yöntemleri. Ankara: Seçkin Publications. 